\title{
Genetic Susceptibility to Type 1 Diabetes Mellitus in Humans
}

\author{
D. KANTÁROVÁ ${ }^{1,2}, \mathrm{M} . \mathrm{BUC}^{3}$
}

${ }^{1}$ Internal Clinic, Comenius University, Jesenius School of Medicine, Martin, ${ }^{2}$ Martin Centre of Immunology, Martin, ${ }^{3}$ Department of Immunology, Comenius University School of Medicine, Bratislava, Slovakia

Received January 30, 2006

Accepted June 21, 2006

On-line available June 22, 2006

\begin{abstract}
Summary
Type 1 diabetes mellitus (DM 1A) is an autoimmune disease belonging to the most frequent chronic diseases of the childhood and young adults. DM 1A results from immune-mediated destruction of the insulin-producing beta cells of the pancreas. It is a genetically determined disease and many genes or genetic regions were found to be associated with its induction. In addition to the insulin-dependent diabetes mellitus 1 (IDDM1) gene, which marks the HLA region, and IDDM2 which marks the insulin gene, significant associations of DM 1A to other IDMM genes or genetic regions we reported. We shortly review recent achievements in the field, and the state of current knowledge.
\end{abstract}

Key words

$\mathrm{CD} 25 \bullet \mathrm{CTLA} 4 \bullet \mathrm{HLA} \bullet \mathrm{IDDM} \bullet$ Insulin $\bullet$ Type 1 diabetes mellitus $\bullet$ PTPN22

\section{Introduction}

Type 1A diabetes mellitus (DM 1A; MIM 222100) is one of the most common chronic diseases of childhood and the most common type of diabetes in persons under 40 years of age. It is the leading cause of blindness, amputations, and end-stage renal disease, and contributes to premature death. The most frequent age of its onset is 12-13 years, but it may occur at any age, in all racial groups, with equal prevalence (about 1/300) in males and females. The incidence of type $1 \mathrm{~A}$ diabetes has been increasing in many countries (Robles and Eisenbarth 2001, Gottlieb and Eisenbarth 2002).

Almost one half of monozygotic twins of patients with DM 1A develops diabetes. The concordance of monozygotic (50\%) and dizygotic (5\%) twins for DM $1 \mathrm{~A}$ differs dramatically. The probability of a monozygotic twin living in different environmental conditions to develop to diabetes decreases with the duration of discordance, but twins can become concordant more than 40 years after the development of diabetes in their twin sibling. The risk for diabetes of a dizygotic twin is more or less similar to the risk of a twin of a patient with diabetes $(5 \%)$. Thus the shared environment of dizygotic twins does not appear substantially enhance the development of diabetes. Expression of anti-islet autoantibodies is much greater for monozygotic twins as compared to dizygotic twins. The majority of monozygotic twins of DM 1A patients expressing anti-islet autoantibodies progresses to diabetes 


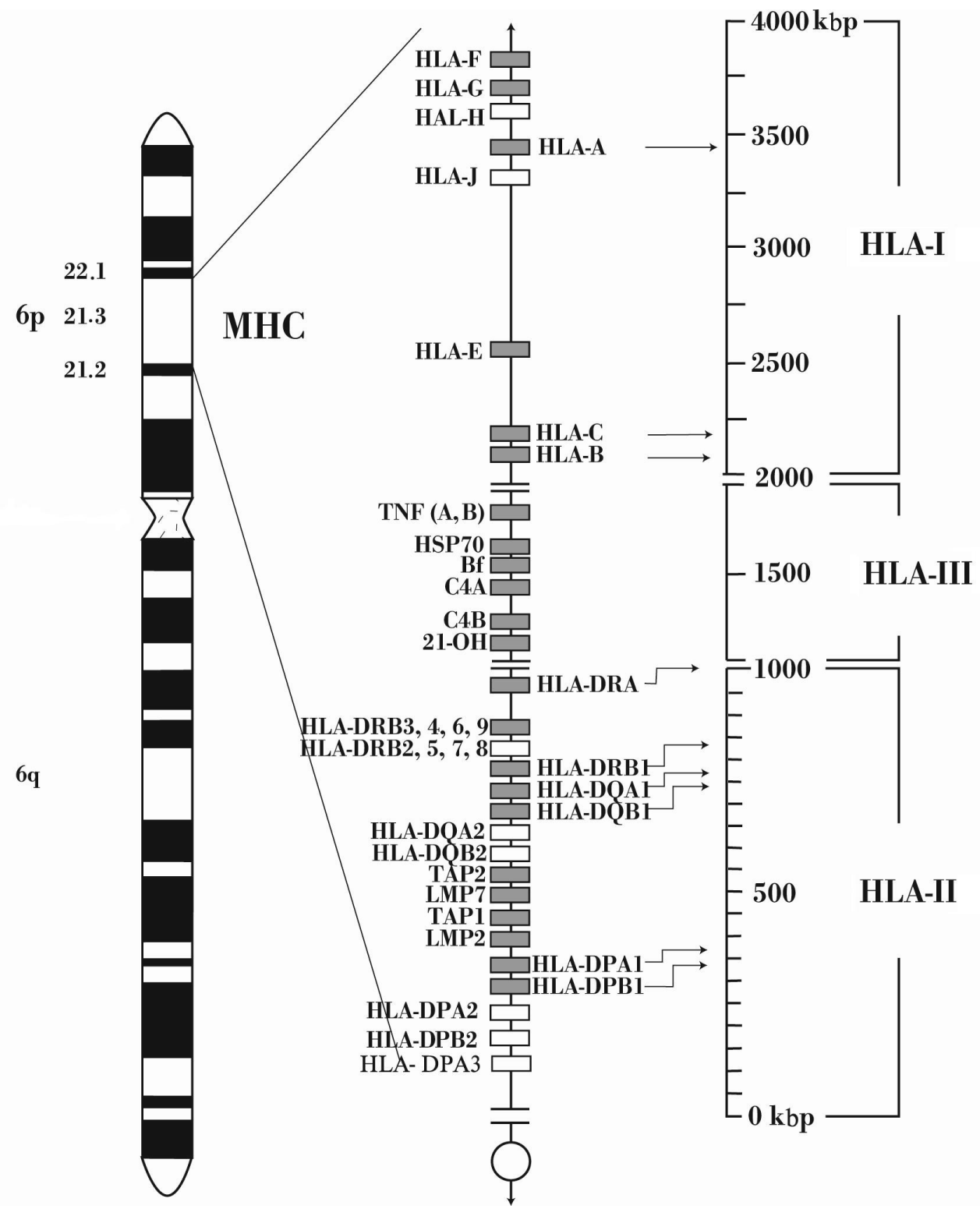

Fig. 1. Genetic region of the major histocompatibility complex in man. The genetic region of the major histocompatibility complex in man, HLA, is located on the short arm of chromosome 6 (6p21.3) and occupies a large segment of DNA, extending for about $3600 \mathrm{kbp}$. It is a region of highly polymorphic genes that form separate gene clusters, class I (telomeric) and class II (centromeric). These two regions are separated by another cluster of unrelated genes, which are called class III genes. The classical class I HLA loci are HLA-A, $-B$, and $-C$, those of class II are HLA-DR (DRA, DRB), -DQ (DQA, DQB) and -DP (DPA, DPB). Class III HLA region comprises the complement genes $\mathrm{C} 2, \mathrm{C} 4, \mathrm{Bf}$, heat shock proteins genes (HSP70), tumour necrosis factor genes (TNF), 21-hydroxylase (21-OH) and others.

(Redondo et al. 1999, Gottlieb and Eisenbarth 2002).

DM 1A results from immune-mediated destruction of the insulin-producing beta cells of the pancreas. Autoimmune diabetes in the non-obese diabetic (NOD) mouse shares many genetic and pathophysiological characteristics with human DM 1A. In both species, the major histocompatibility complex (MHC) and multiple non-MHC genes contribute to disease susceptibility. However, the genes of the MHC confer the highest relative risks of disease development, between
3 to 50 for the most predisposing haplotypes and genotypes compared to less than 3 of non-MHC genes.

\section{HLA genes in predisposition to DM 1A}

The genetic region of the major histocompatibility complex in man, HLA (human leukocyte antigens), is located on the short arm of chromosome 6 (6p21.3) and occupies a large segment of DNA, extending about $3600 \mathrm{kbp}$, i.e. in classical terms, 
$3.6 \mathrm{cM}$. It is a region of highly polymorphic genes that form separate gene clusters, class I (telomeric) and class II (centromeric). These two regions are separated by another cluster of unrelated genes called class III (for review see Buc 1993, 2005, Žalkovičová et al. 1998) (Fig. 1). A major determinant of genetic susceptibility resides in the HLA class II region. HLA class II molecules, particularly DR and DQ, account for approximately $40 \%$ of the genetic risk for DM 1A development (Jones et al. 2006). As the HLA region displays a significant degree of linkage disequilibrium (i.e. specific DQ and DR alleles are non-randomly associated with each other), associations of HLA alleles with disease must be considered as haplotype specific and not allele specific. HLA class I alleles can also influence the disease, and it is possible that unknown genes linked to the HLA region are also important.

Individuals with the highest risk for type 1A diabetes express both predisposing haplotypes: DQA1*0501-DQB1*0201 (DQ2), which is almost always inherited with DRB1*0301 (DR3) and DQA1*0301DQB1 *0302 (DQ8), inherited with DRB1*0401 or DRB1*0402 (DR4) (Chowdhury et al. 1999, Nepom 2000, Černá et al. 2003, Buc et al. 2006). These individuals have been referred to as DR3/DR4 or DQ2/DQ8 heterozygotes. Individuals who carry this high risk haplotypic combination have $\sim 5 \%$ absolute risk of DM 1A. However, within affected families, this genotype has $\sim 20 \%$ risk; approximately $40 \%$ of diabetic children have this genotype compared to $2 \%$ of children in the healthy population (Chowdhury et al. 1999, Nepom 2000, Concannon et al. 2005). Observations of transmission frequencies of particular haplotypes have helped to illustrate the importance of certain haplotypes in contributing to diabetes susceptibility. For example, analysis of Human Biological Data Interchange (www.ncbi.nlm.nih.gov) family collection has revealed that DQA1*0501-DQB1*0201 and DQA1*0301DQB1*0302 are transmitted to more than $80 \%$ of diabetic children.

HLA-alleles have also been associated with protection from type $1 \mathrm{~A}$ diabetes, especially the haplotype DQA1*0102/DQB1*0602/DRB1*1501 confers protection. Evidence suggests that such protection may mostly be encoded by the DQB1*0602 allele and even the first-degree relatives with islet cell antibodies (ICA) have a low diabetes risk if they carry DQB1*0602. However, this protective effect is not absolute (Chowdhury et al. 1999, Redondo et al. 2000, Sanjeevi
2000, Greenbaum et al. 2002). To summarize, as some HLA haplotypes are associated with high, moderate, low risks and even "protection", their identification is useful in disease prediction (Table 1).

Table 1. Spectrum of diabetes risk HLA haplotypes

\section{High risk haplotypes}

\begin{tabular}{llll}
\hline DR3 & DRB1*0301 & DQA1*0501 & DQB1*0201 \\
DR4 & DRB1*0401 & DQA1*0301 & DQB1*0302 \\
& DRB1*0402 & DQA1*0301 & DQB1*0302 \\
& DRB1*0405 & DQA1*0301 & DQB1*0302 \\
\hline
\end{tabular}

Moderate risk haplotypes

\begin{tabular}{llll}
\hline DR1 & DRB1*01 & DQA1*0101 & DQB1*0501 \\
DR8 & DRB1*0801 & DQA1*0401 & DQB1*0402 \\
DR9 & DRB1*0901 & DQA1*0301 & DQB1*0303 \\
\hline
\end{tabular}

\section{Protective haplotypes}

\begin{tabular}{llll}
\multicolumn{3}{l}{ Strong protection } \\
DR2 & DRB $1 * 1501$ & DQA1*0102 & DQB1*0602 \\
DR6 & DRB $1 * 1401$ & DQA $1 * 0101$ & DQB $1 * 0503$ \\
DR7 & DRB $1 * 0701$ & DQA $1 * 0201$ & DQB $1 * 0303$
\end{tabular}

Moderate protection

DR5 DRB1*1101 DQA1-0501 DQB1*0301

Weak protection

$\begin{array}{llll}\text { DR4 } & \text { DRB1*0401 } & \text { DQAl*0301 } & \text { DQB1*0301 } \\ & \text { DRB1*0403 } & \text { DQAl*0301 } & \text { DQB1*0302 } \\ \text { DR7 } & \text { DRB1*0701 } & \text { DQAl*0201 } & \text { DQB1*0201 }\end{array}$

There are also some reports on association between the last group of class II HLA alleles and DM 1A. HLA-DPB1*0101, DPB1*0301 and DPB $1 * 0202$ were reported to be positively and DPB1*0402 negatively associated (Noble et al. 2000, Valdes et al. 2001, Stuchlíková et al. 2006).

\section{The insulin gene}

The second well established susceptibility locus in DM $1 \mathrm{~A}$ is on chromosome $11 \mathrm{p} 15.5$, which is mapped to a region containing the variable number of tandem repeat (VNTR) polymorphism in the promoter region of the insulin gene. This VTNR region is categorized into classes I to III. VNTR I contains 26-63 repeating units 
(5' - - ACAGGGGTGGTGGGG - - - 3'), VNTR II 80 units, and VNTR III 140-210 units, respectively. Occurrence rate of VNTR I in the Caucasian population is approximately $70 \%$, that of VNTR III $30 \%$, and VNTRII occurs very rarely.

VNTR I homozygous individuals develop DM 1A more likely than those with VNTR III; VNTRII is associated with resistance to the disease induction (Bennet et al. 1995, Barrat et al. 2004, Maier and Wicker 2005, Královičová et al. 2006).

The thymic expression of insulin, and the deletion of autoreactive $\mathrm{T}$ cells during the process of negative selection, is under regulation of the transcription factor AIRE (autoimmune regulator) (Venazi et al. 2004, Villasenor et al. 2005, Buc, 2005). The type of the VNTR promoter region of the insulin gene may therefore influence the binding of AIRE transcription factor. Thus VNTR I allele predispose to DM 1A by reducing tolerance to insulin and its precursors via lower insulin transcription in thymic medullary epithelial cells. These reports are consistent with studies demonstrating that positivity for insulin autoantibodies has a high predictive value for DM 1A (Kukko et al. 2005).

HLA and insulin (INS) regions account for almost $60-70 \%$ of the familial aggregation of type $1 \mathrm{~A}$ diabetes. In some populations, the combined effects of HLA and INS contribute less than $50 \%$ of the familial increased diabetes risk. Therefore, several genome-wide linkage studies have been conducted to identify candidate regions that may contain unidentified susceptibility genes. About 20 candidate regions for diabetes genes have been reported in linkage studies of affected sibling pairs (Concannon et al. 2005). Most of the known or suspected susceptibility loci have been designated IDDM, e.g. IDDM1 refers to genes mapping to the HLA region at $6 \mathrm{p} 21$, IDDM2 to the insulin region at $11 \mathrm{pl}$ etc. (Table 2). Although the statistical analysis varies across studies, none of the proposed susceptibility loci has an effect as strong as that associated with the HLA region on chromosome 6. An added complexity has been the inability to confirm certain loci in different population groups. This might occur if the identified regions are "false" positive associations or if different combinations of non-HLA genes contribute to autoimmune diabetes in different populations (Pociot and McDermott 2002, Concannon et al. 2005).

In disorders following a Mendelian pattern of autosomal dominant or recessive transmission, the pattern of inheritance of the disease phenotype is usually obvious. It is much more difficult to confidently define the reported linkages to diabetes susceptibility genes, since the mode of inheritance of the genes causing these complex disorders is unknown. There is considerable controversy regarding the interpretation of linkage studies for complex diseases. The LOD score has been used as a measure of the statistical evidence for linkage between a marker and a gene. In fact, the primary motivation for genome-wide linkage searches is to provide definitive evidence that one or more of such genes exist. "Lamda-s" values reflecting sibling risk of a disease in relation to its population prevalence are calculated, too. In DM 1A they are in the range 2.5 to 4.5 for HLA compared to 1.0-1.6 for other IDDM loci (Table 2).

\section{Cytotoxic T lymphocyte antigen-4 (CTLA-4)}

The CTLA-4 gene is localized on the long arm of chromosome 2 (2q33) and this genetic region, IDDM12, was previously found to be associated with the predisposition to type 1 diabetes mellitus. Later it was proved that this association belongs to CTLA-4 gene (Kristiansen et al. 2000a, Ueda et al. 2003).

CTLA-4, a disulfide-linked homodimer expressed on the cell surface of activated T-cells is responsible for attenuation of the immune response by binding to ligands CD80 or CD86 expressed on the surface of antigen presenting cells. The CTLA-4 CD80/CD86 interaction down-regulates the alpha chain of IL-2 receptor (CD25) expression what is followed by a decreased synthesis of IL-2 or may induce apoptosis in previously activated cells (Noel et al. 1996, Bucová 2002). CTLA-4 is also an important molecule by which $\mathrm{CD}^{+} \mathrm{CD} 25^{+} \mathrm{T}$ regulatory cells (Treg) exert their suppressive activity (Paust et al. 2004). They represent naturally occurring population of $\mathrm{CD}^{+} \mathrm{T}$ cells that are vital in the control of autoimmune and inflammatory responses.

Because of the important role in regulation of the immune response, CTLA4 is a very strong candidate for association with autoimmune diseases. Indeed, the associations of CTLA-4 polymorphism with autoimmune diseases, such as Graves's disease, autoimmune hepatitis were reported. As for DM 1A, important associations were also found. The association was found in the $3^{\prime}$ flanking region, downstream of the previously known polyadenylation site; it is a single nucleotide polymorphism (SNP): $+6230 \mathrm{G}>\mathrm{A}$. This polymorphism may be associated with altered levels of steady state 
Table 2. DM 1 A susceptibility loci.

\begin{tabular}{|c|c|c|c|c|}
\hline Locus & Region & $\lambda_{\mathrm{s}}{ }^{*}$ & LOD & References \\
\hline IDDM1 $(H L A)$ & $6 \mathrm{p} 21$ & $1.7-4.2$ & 65.8 & Cox et al. 2001 \\
\hline IDDM2 (INS) & $11 \mathrm{p} 15$ & 1.6 & 4.28 & Davies et al. 1994, Cox et al. 2001 \\
\hline IDDM3 & $15 q 26$ & & & Zamani et al. 1996 \\
\hline IDDM4 & $11 \mathrm{q} 13$ & $1.0-1.5$ & 2.7 & Nakagawa et al. 1998 \\
\hline IDDM5 & $6 \mathrm{q} 25$ & & 4.5 & Luo et al. 1996 \\
\hline IDDM6 & $18 \mathrm{q} 12-\mathrm{q} 21$ & $1.0-1.5$ & 1.1 & Laine et al. 2004 \\
\hline IDDM7 & $2 \mathrm{q} 31$ & $1.0-1.6$ & 1.2 & Copeman et al. 1995 , Kristiansen et al. $2000 \mathrm{~b}$ \\
\hline IDDM8 & $6 q 27$ & $1.0-2.1$ & 3.6 & Luo et al. 1996 \\
\hline IDDM9 & $3 q 22-q 25$ & $1.0-1.7$ & 3.4 & Laine et al. 2006 \\
\hline IDDM10 & $10 p 11-q 11$ & $1.1-2.2$ & 2.8 & Cox et al. 2001, Mein et al. 1998 \\
\hline IDDM11 & $14 q 24-q 31$ & & 4.0 & Field et al. 1996 \\
\hline IDDM12 (CTLA4) & $2 q 31-q 33$ & & 3.57 & Marron et al. 1997, Cox et al. 2001 \\
\hline IDDM13 $3^{* *}$ & $2 q 34-q 35$ & & & Larsen et al. 1999 \\
\hline IDDM15 & $6 \mathrm{q} 21$ & & 2.36 & Delepine et al. 1997, Cox et al. 2001 \\
\hline IDDM16 (IGH) & $14 \mathrm{q} 32$ & & & Field et al. 2002 \\
\hline IDDM17 & $10 \mathrm{q} 25$ & & 2.38 & Babu et al. 2004 \\
\hline \multirow[t]{5}{*}{ IDDM18 (IL-12p40) } & $5 q 33$ & & & Luo et al. 1996, Morahan et al. 2001 \\
\hline & $7 \mathrm{q} 25$ & & 1.81 & Cox et al. 2001 \\
\hline & $16 \mathrm{q} 22-\mathrm{q} 24$ & 1.6 & 3.93 & Cox et al. 2001 \\
\hline & $1 \mathrm{q} 42$ & & 2.2 & Cox et al. 2001 \\
\hline & $8 q 22-q 24$ & & 2.4 & Sale et al. 2002 \\
\hline
\end{tabular}

IGH - immunoglobulin heavy chain, " Gottlieb and Eisenbarth 2002, **The symbol IDDM14 has been reserved but not published.

mRNA of a soluble CTLA-4 through as yet unknown mechanisms (Marron et al. 1997, Ueda et al. 2003).

In addition to the effect of the 3'-flanking $+6230 \mathrm{G}>\mathrm{A}$ on splicing or RNA stability, there are also promoter polymorphisms that could contribute to the DM-1A association through transcriptional effects on expression. Anjos et al. (2004) found that the promoter polymorphism, $-319 \mathrm{C}>\mathrm{T}$, is highly associated with the disease.

Another association between CLTA-4 and DM 1A is related to the position +49 of the CTLA-1 gene. The non-synonymous $+49 \mathrm{~A}>\mathrm{G}$ base substitution is responsible for Thr17Ala change in the signal peptide. The predisposing Ala17 allele is incompletely glycosylated in the endoplasmic reticulum leading to retrograde transport of a portion of the molecules into the cytoplasm for degradation. This ultimately results in less CTLA-4 (Ala17) at the cell surface, which may explain the reduced inhibitory function of CTLA-4 reported in patients with $+49 \mathrm{G}$ allele (Anjos et al. 2002, Mauer et al. 2002).

\section{PTPN22 is associated with autoimmune disease}

The fourth established human DM 1A susceptibility locus is PTPN22 (protein tyrosine phosphatase non-receptor type $22 ; 1 \mathrm{p} 13)$. It encodes a lymphoid protein tyrosine kinase (LYP) that is important on the negative control of T-cell activation and in T-cell development. A non-synonymous single nucleotide polymorphism at nucleotide 1858 in codon 620 (Arg620Trp) in PTPN22 was associated with type 1 diabetes (Smyth et al. 2004). The disease-associated variant Trp620 may alter the binding of LYP to the cytoplasmic tyrosine kinase (Bottini et al. 2004), which regulates the T-cell receptor-signaling kinases, T-cellspecific protein tyrosine kinase (LCK) and FYN, respectively (Hill et al. 2002), ultimately leading to hyperreactive $\mathrm{T}$ cell responses. Similar to CTLA4, PTPN22 is a DM 1A susceptibility locus that is shared by several organ-specific and systemic autoimmune diseases (rheumatoid arthritis, systemic lupus eruthematosus) (Maier and Wicker 2005). 
Association with the gene encoding the alpha chain of the IL-2 receptor

It is well recognized that interleukin-2 (IL-2) has paradoxical functions in $\mathrm{T}$ cell homeostasis, acting as a potent $\mathrm{T}$ cell growth factor during the initiation of immune responses and having a crucial function in the termination of $\mathrm{T}$ cell responses and maintenance of selftolerance. The latter function has been proposed to be due to a requirement for IL-2 signaling for the development and function of regulatory T cells (Treg). Although IL-2 signaling is not required for their development in the thymus, it is critical for maintaining Treg cells in the peripheral $\mathrm{T}$ cell pool. Its levels might therefore affect disease susceptibility via the mechanisms that maintain immune homeostasis. It has been proved that although the levels of $\mathrm{CD} 4^{+} \mathrm{CD} 25^{+}$regulatory $\mathrm{T}$ cells were normal in patients with DM 1A, their ability to suppress T-cell proliferation during in vitro co-cultures was markedly reduced compared with control subjects (Lindley et al. 2005, Maloy and Powrie 2005). Moreover, these cocultures displayed a more pro-inflammatory phenotype, with increased secretion of IFN- $\gamma$ and decreased IL-10 production. From this point of view, it is very interesting that the region containing the gene IL2RA encoding the alpha chain of the IL-2 receptor (CD25) on chromosome 10p15-p14 could be the fifth susceptibility locus for human DM 1A (Vella et al. 2005).

\section{Other IDDM loci involved in susceptibility to DM 1A}

IDDM4 is a region on chromosome $11 \mathrm{q} 13$ and one of its genes which might be involved in DM 1A genetic predisposition, can be that coding for FADD (Fas-associated death domain containing protein), a molecule involved in the apoptosis process (Nakagawa et al. 1998). IDDM7 on chromosome 2q31-33 may be identical with NeuroD gene that is involved in morphogenesis of beta cells of Langerhans islets (Copeman et al. 1995, Esposito et al. 1998). NRAMP1 gene (natural resistance associated macrophage protein) is probably identical with $I D D M 13$, a region on the long arm of chromosome 2 (2q34-35) (Esposito et al. 1998). It encodes a protein responsible for macrophage resistance to intracellular parasitic bacteria. NRAMP1 is also associated with a susceptibility to rheumatoid arthritis (Shaw et al. 1996), which indicates that more autoimmune disorders will share susceptibility genes.
$\operatorname{IDDM18}(5 \mathrm{q} 31.1-\mathrm{q} 33.1)$ is a genetic region harboring p40 chain of interleukin 12 (IL-12) (Bergholdt et al. 2004). IL-12 is a disulphide linked heterodimer composed of a heavy chain of $\mathrm{Mr} 40000$, p40, and a light chain of $\mathrm{Mr} 35000$, p35, encoded by their respective genes. The gene for the p35 subunit is located on chromosome 3p12-q13.2. The heterodimer is the biologically active IL-12. It drives the differentiation of $\mathrm{T}$ cells towards the TH1 subset, characterized by production of cytokines leading to cell mediated immunity. IL-12induced autoreactive $\mathrm{T}$ cell responses might predispose to self destructive immunity. Finally, there is also a report on the association of CD4 SNP promoter polymorphism and type 1 diabetes mellitus (Kristiansen et al. 2004). $\mathrm{CD} 4$ is a principal differentiation antigen of $\mathrm{T}$ helper cells involved in cell cooperation and signal transduction.

A search for the genetic determination of type 2 diabetes mellitus (T2 DM non-insulin-dependent diabetes mellitus) has also been performed. Several studies have reported an increased frequency of T2 DM in families with type 1 diabetes (Dahlquist et al. 1989, Corel et al. 1993, Martinka et al. 1999, Li et al. 2001). On the other hand, frequent occurrence of $\mathrm{DM} 1 \mathrm{~A}$ in relatives of patients with T2 DM has been observed (Quatraro et al. 1987, Gottlieb 1980). A parental history of T2 DM is associated with an increased risk of DM $1 \mathrm{~A}$ in siblings of type 1 diabetic patients (Wagener et al. 1982). Thus, type 1 diabetes susceptibility genes could contribute to the polygenic etiology of type 2 diabetes and modify its clinical manifestation.

\section{Environmental factors}

The annual incidence of type 1 diabetes mellitus amongst children varies dramatically from more than 40 per 100000 children in Finland to less than 2 per 100000 in Japan (Onkamo et al. 1999, Gottlieb and Eisenbarth 2002). In addition, there is compelling evidence of a temporal increase in the incidence of DM 1A, with countries such as Finland experiencing more than a doubling in incidence over the past four decades (Drykoningen et al. 1996, Gardner et al. 1997). How much of the variation in incidence between countries is due to environmental factors and how much is due to genetic differences between populations is unknown. For Sardinia, with one of the highest incidences of childhood diabetes in the world, the major factor appears to be genetics, as migrants from Sardinia to the Italian mainland have maintained their high incidence of type 1 
diabetes (Muntoni et al. 1997).

The temporal increase in the incidence of DM $1 \mathrm{~A}$ is almost certainly due to environmental factors. Moreover, it was noted that the incidence of diabetes had seasonal variation with an increase in children presenting with the disorder in the fall and winter suggesting viral infections might precipitate the disease. A series of virus candidates include picornaviruses, rotaviruses, herpesviruses, mumps, rubella, and retroviruses (Yoon et al. 1979, Dahlquist 1998, Gottlieb and Eisenbarth 2002). Coxsackie viruses have been of particular interest because of a homology between the virus and the target antigen glutamic acid decarboxylase 65 (GAD65); both negative and positive studies have been reported (Atkinson et al. 1994, Horwitz et al. 1998, Heino et al. 2001). A possible explanation for the lack of definitive association between viral infection and diabetes induction may derive from the fact that viral factors are ubiquitous and not unique to those with diabetes.

Nutritional factors were suggested to induce immunopathological processes, too. Antibodies to milk proteins and $\mathrm{T}$ cell responses to these proteins were reported to be increased among children with DM 1A. This includes a molecule ICA69 with some homology to bovine albumin (Stassi et al. 1997). Moreover, certain forms of milk casein vary in their protein sequence and might be converted to peptides cross-reactive to peptides derived from self-proteins (Elliot et al. 1999). A number of retrospective studies have implicated early ingestion of milk to the development of diabetes. The increased risk in most of these studies is, however, small and prospective studies following children till the expression of autoimmunity have failed to find an association between milk ingestion and anti-islet autoimmunity (Norris et al. 1996).

Overall, the search for environmental factors contributing to the development of diabetes has been relatively disappointing. With the exception of congenital rubella infection, none has been confirmed. Prospective studies will perhaps bring more light to the problem.

\section{Conclusions}

The functions of gene products of so far established type I diabetes mellitus loci in humans and the NOD mouse suggest that a fine balance in $\mathrm{T}$ cell development, expansion, homeostasis and reactivity needs to be maintained to protect against autoimmune destruction of the pancreatic islets. The arrival of modern genotyping technologies and availability of large numbers of SNPs across the genome will make the discovery of many more genes possible. The identified susceptibility genes will aid in disease prediction and provide an insight into the underlying DM1A etiology and pathology, and possibly uncover as yet unexplored avenues leading to disease prevention and/or treatment.

\section{Acknowledgements}

The study was supported by the Research Programs of the Ministry of Education of the Slovak Republic VEGA $1 / 3437 / 06$ and $1 / 4284 / 07$.

\section{Abbreviations}

$\mathrm{cM}$ - centiMorgan

kbp - kilobase pairs

LOD - logarithm of the odds

MIM - Mendelian inheritance in man

\section{References}

ANJOS S, NGUYEN A, OUNISSI-BENKALHA H, TESSIER MC, POLYCHRONAKOS C: A common autoimmunity predisposing signal peptide variant of the cytotoxic T-lymphocyte antigen 4 results in inefficient glycosylation of the susceptibility allele. J Biol Chem 277: 46478-46486, 2002.

ANJOS SM, TESSIER MC, POLYCHRONAKOS C: Association of the cytotoxic T lymphocyte-associated antigen 4 gene with Type 1 Diabetes: evidence for independent effects of two polymorphisms on the same haplotype block J Clin Endocrinol Metab 89: 6257-6265, 2004.

ATKINSON MA, BOWMAN MA, CAMPBELL L, DARROW BL, KAUFMAN DL, MACLAREN N: Cellular immunity to a determinant common to glutamate decarboxylase and coxsackie virus in insulin-dependent diabetes. J Clin Invest 94: 2125-2129, 1994.

BABU SR, CONANT GC, ELLER E, ROBERTS CM, GOWAN K, EISENBARTH GS, FAIN PR, VARDI P: A second-generation genome screen for linkage to type 1 diabetes in a Bedouin Arab family. Ann N Y Acad Sci 1037: 157-160, 2004. 
BARRAT BJ, PAYNE F, LOWE CE, HERMANN R, HEALY BC, HAROLD D, CONCANNON P, GHARANI N, MCCARTHY MI, OLAVESEN MG: Remapping the insulin gene/IDDM2 locus in type 1 diabetes. Diabetes 53: 1884-1889, 2004.

BENNET ST, LUCASSEN AM, GOUGH SC, POWELL EE, UDLIEN DE, PRITCHARD LE, MERRIMN ME, KAWAGUCHI Y, DRONSFIELD MJ, POCIOT F: Susceptibility to human type diabetes at IDDM2 is determined by tandem repeat variation at the insulin gene minisatellite locus. Nat Genet 9: 284-292, 1995.

BERGHOLDT R, GHANDIL P, JOHANNESEN J, KRISTIANSEN OP, KOCKUM I, LUTHMAN H, RØNNINGEN KS, NERUP J, JULIER C, POCIOT F: Genetic and functional evaluation of an interleukin-12 polymorphism (IDDM18) in families with type 1 diabetes. $J$ Med Genet 41: e39, 2004.

BOTTINI N, MUSUMECI L, ALONSO A, RAHMOUNI S, NIKA K, ROSTAMKHANI M, MACMURRAY J, MELONI GF, LUCARELLI P, PELLECCHIA M, EISENBARTH GS, COMINGS D, MUSTELIN T: A functional variant of lymphoid tyrosine phosphatase is associated with type I diabetes. Nat Genet 36: 337-338, 2004.

BUC M: A review: The major histocompatibility complex in man. Folia Biol (Prague) 39: 223-242, 1993.

BUC M: Autoimmunity and Autoimmune Diseases (in Slovak). Veda, Bratislava, 2005, 492 pp.

BUC M, BUCOVÁ M, JAVOR J, KRIVOŠÍKOVÁ M, STUCHLÍKOVÁ M, SHAWKATOVÁ I., MICHALKOVÁ D, BARÁK L', JANČOVÁ E, PETŘEK M: Associations between HLA class II alleles and type 1 diabetes mellitus in the Slovak population. Endocr Regul 40: 1-6, 2006.

BUCOVÁ M: A role of cytokines in local and systemic inflammation, and septic shock. (in Slovak) Vnitr Lek 48: 755$762,2002$.

CAREL JC, BOITARD C, BOUGNERES PF: Decreased insulin response to glucose in islet cell antibody-negative siblings of type 1 diabetic children. J Clin Invest 92: 509-513, 1993.

ČERNÁ M, NOVOTA P, KOLOSTOVÁ K, ČEJKOVÁ P, ŽĎÁRSKÝ E, NOVÁKOVÁ D, KUČERA P, NOVÁK J, ANDĚL M: HLA in Czech adult patients with autoimmune diabetes mellitus: comparison with Czech children with type 1 diabetes and patients with type 2 diabetes. Eur J Immunogenet 30: 401-407, 2003.

CHOWDHURY TA, MIJOVIC CH, BARNETT AH: The aetiology of type I diabetes. Clin Baillieres Best Pract Res Clin Endocrinol Metabol 13: 181-195, 1999.

CONCANNON P, ERLICH HA, JULIER C, MORAHAN G, NERUP J, POCIOT F, TODD JA, RICH SS, The Type 1 Diabetes Genetics Consortium: Type 1 Diabetes: evidence for susceptibility loci from four genome-wide linkage scans in 1,435 multiplex families. Diabetes 54: 2995-3001, 2005.

COPEMAN JB, CUCCA F, HEARNE CM, CORNALL RJ, REED PW, RONNINGEN KS, UNDLIEN DE, NISTICO L, BUZZTTI R, TOSI R: Linkage disequilibrium mapping of a type 1 diabetes susceptibility gene (IDDM7) to chromosome 2q31-q33. Nat Genet 9: 80-85, 1995.

COX NJ, WAPELHORST B, MORRISON VA, LINDSEY JOHNSON L, LESYA PINCHUK L, SPIELMAN RS, JOHN A. TODD JA, CONCANNON P: Seven regions of the genome show evidence of linkage to type 1 diabetes in a consensus analysis of 767 multiplex families. Am J Hum Genet 69: 820-830, 2001.

DAHLQUIST G: The aetiology of type 1 diabetes: an epidemiological perspective. Acta Paediatr Suppl 425: 5-10, 1998.

DAHLQUIST G, BLOM L, TUVEMO T, NYSTROM L, SANDSTROM A, WALL S: The Swedish childhood diabetes study-results from a nine-year case register and a one-year case-referent study indicating that type 1 (insulindependent) diabetes mellitus is associated with both type 2 (non-insulin-dependent) diabetes mellitus and autoimmune disorders. Diabetologia 32: 2-6, 1989.

DAVIES JL, KAWAGUCHI Y, BENNETT ST, COPEMAN JB, CORDELL HJ, PRITCHARD LE, REED PW, GOUGH SC, JENKINS SC, PALMER SM: A genome-wide search for human type 1 diabetes susceptibility genes. Nature 371: 130-136, 1994.

DELEPINE M, POCIOT F, HABITA C, HASHIMOTO L, FROGUEL P, ROTTER J, CAMBON-THOMSEN A, DESCHAMPS I, DJOULAH S, WEISSENBACH J, NERUP J, LATHROP M, JULIER C: Evidence of a nonMHC susceptibility locus in type I diabetes linked to HLA on chromosome 6. Am J Hum Genet 60: 174-187, 1997. 
DRYKONINGEN CE, MULDER AL, VAANDRAGER GJ, LAPORTE RE, BRUINING GJ: The incidence of male childhood type 1 (insulin-dependent) diabetes mellitus is rising rapidly in the Netherlands. Diabetologia 35 : 139-142, 1992.

ELLIOTT RB, HARRIS DP, HILL JP, BIBBY NJ, WASMUTH HE: Type I (insulin-dependent) diabetes mellitus and cow milk: casein variant consumption. Diabetologia 42: 292-296, 1999.

ESPOSITO L, HILL NJ, PRITCHARD LE, CUCCA F, MUXWORTHY C, MERRIMAN ME, WILSON A, JULIER C, DELEPINE M, TUOMILEHTO J, TUOMILEHTO-WOLF E, IONESCO-TIRGOVISTE C, NISTICO' L BUZZETTI R, POZZILLI P, FERRARI M, BOSI E, POCIOT F, NERUP J, BAIN SC, TODD JA: Genetic analysis of chromosome 2 in type 1 diabetes: analysis of putative loci IDDM7, IDDM12, and IDDM13 and candidate genes NRAMP1 and IA-2 and the interleukin-1 gene cluster. Diabetes. 47: 1797-1799, 1998.

FIELD LL, TOBIAS R, THOMSON G, PLON S: Susceptibility to insulin-dependent diabetes mellitus maps to a locus (IDDM11) on human chromosome 14q24.3-q31. Genomics 33: 1-8, 1996.

FIELD LL, LARSEN Z, POCIOT F, NERUP J, TOBIAS R, BONNEVIE-NIELSEN V: Evidence for a locus (IDDM16) in the immunoglobulin heavy chain region on chromosome 14q32.3 producing susceptibility to type 1 diabetes. Genes Immun 3: 338-344, 2002.

HILL RJ, ZOZULYA S, LU YL, WARD K, GISHIZKY M, JALLAL B: The lymphoid protein tyrosine phosphatase Lyp interacts with the adaptor molecule Grb2 and functions as a negative regulator of T-cell activation. Exp Hematol 30: 237-244, 2002.

GARDNER SG, BINGLEY PJ, SAWTELL PA, WEEKS S, GALE EA: Rising incidence of insulin dependent diabetes in children aged under 5 years in the Oxford region: time trend analysis. The Bart's-Oxford Study Group. BMJ 315: 713-717, 1997.

GOTTLIEB MS: Diabetes in offspring and siblings of juvenile- and maturity-onset-type diabetics. J Chronic Dis 33: 331-339, 1980.

GOTTLIEB PA, EISENBARTH GS: Human Autoimmune Diabetes. In: Molecular Pathology of Autoimmune Diseases. AN THEOFILOPOULOS, CA BONA (eds), Taylor \& Francis, New York, 2002, pp 588-613.

GREENBAUM CJ, GAUR LK, NOBLE JA: ICA ${ }^{+}$relatives with DQA1*0102/ DQB1*0602 have expected 0602 sequence and DR types. $J$ Autoimmun 18: 67-70, 2002.

HEINO L, LÖNNROT M, KNIP P, KUPILA A, ERKKILA S, TOIVONEN A, VAHASALO P, ILONEN J, SIMELL O, HYOTY H: No evidence of abnormal regulation of antibody response to coxackievirus B4 antigen in prediabetic children. Clin Exp Immunol 126: 432-436. 2001.

HORWITZ MS, BRADLEY LM, HARBERTSON J, KRAHL T, LEE J, SARVETNICK N: Diabetes induced by Coxsackie virus: initiation by bystander damage and not molecular mimicry. Nat Med 7: 781-785, 1998.

JONES EY, FUGGER L, STROMINGER JL, SIEBOLD CH: MHC class II proteins and disease: a structural perspective. Nat Rev Immunol 6: 271-282, 2006.

MALOY KJ, POWRIE F: Fueling regulation: IL-2 keeps CD4 ${ }^{+}$Treg cells fit. Nat Immunol 6: 1071-1072, 2005.

KRÁLOVIČOVÁ J, GAUNT TR, RODRIGUEZ S, WOOD PJ, DAY IN, VOŘECHOVSKÝ I: Variants in the human insulin gene that affect pre-mRNA splicing: is $-23 \mathrm{HphI}$ a functional single nucleotide polymorphism at IDDM2? Diabetes 55: 260-264, 2006.

KRISTIANSEN OP, LARSEN ZM, POCIOT F: CTLA-4 in autoimmune diseases - a general susceptibility gene to autoimmunity? Genes Immun 1: 170-184, 2000a.

KRISTIANSEN OP, POCIOT F, BENNETT EP, CLAUSEN H, JOHANNESEN J, NERUP J, MANDRUP-POULSEN T: IDDM7 links to insulin-dependent diabetes mellitus in Danish multiplex families but linkage is not explained by novel polymorphisms in the candidate gene GALNT3. Hum Mut 15: 295-296, $2000 \mathrm{~b}$.

KRISTIANSEN OP, KARLSEN AE, LARSEN ZM, JOHANNESEN J, POCIOT F, MANDRUP-POULSEN T: Identification of a type 1 diabetes-associated CD4 promoter haplotype with high constitutive activity. Scand $J$ Immunol 59: 582-591, 2004. 
KUKKO M, KIMPIMAKI T, KORHONEN S, KUPILA A, SIMELL S, VEIJOLA R, SIMELL T, ILONEN J, SIMELL O, KNIP M: Dynamics of diabetes-associated autoantibodies in young children with human leukocyte antigenconferred risk of type 1 diabets recruited from the general population. J Clin Endocrinol Metab 90: 2712-2717, 2005.

LAINE AP, NEJENTSEV S, VEIJOLA R, KORPINEN E, SJOROOS M, SIMELL O, KNIP M, AKERBLOM HK, ILONEN J: A linkage study of 12 IDDM susceptibility loci in the Finnish population. Diabetes Metab Res Rev 20: 144-149, 2004.

LAINE AP, TURPEINEN H, VEIJOLA R, HERMANN R, SIMELL O, KNIP M, ILONEN J: Evidence for linkage to and association with type 1 diabetes at the 3q21 region in the Finnish population. Genes Immun 7: 69-72, 2006.

LARSEN ZM, KRISTIANSEN OP, MATO E, JOHANNESEN J, PUIG-DOMINGO M, DE LEIVA A, NERUP J, POCIOT F: IDDM12 (CTLA4) on 2q33 and IDDM13 on 2q34 in genetic susceptibility to type 1 diabetes (insulin-dependent). Autoimmunity 31: 35-42, 1999.

LI H, LINDHOLM E, ALMGREN P, GUSTAFSSON Å, FORSBLOM C, LEIF GROOP L, TUOMI T: Possible human leukocyte antigen-mediated genetic interaction between type 1 and type 2 diabetes. J Clin Endocrinol Metab 86: 574-582, 2001.

LINDLEY S, DAYAN CM, BISHOP A, ROEP BO, PEAKMAN M, TREE TI: Defective suppressor function in $\mathrm{cd} 4^{+} \mathrm{cd} 25^{+} \mathrm{T}$-cells from patients with type 1 diabetes. Diabetes 54: 92-99, 2005.

LUO DF, BUZZETTI R, ROTTER JI, MACLAREN NK, RAFFEL LJ, NISTICO L, GIOVANNINI C, POZZILLI P, THOMSON G, SHE JX: Confirmation of three susceptibility genes to insulin-dependent diabetes mellitus: IDDM4, IDDM5 and IDDM8. Hum Mol Genet 5: 693-698, 1996.

MAIER LM, WICKER LS: Genetic susceptibility to type 1 diabetes. Curr Opin Immunol 17: 601-608, 2005.

MARRON MP, RAFFEL LJ, GARCHON HJ, JACOB CO, SERRANO-RIOS M, MARTINEZ LARRAD MT, TENG WP, PARK Y, ZHANG ZX, GOLDSTEIN DR, TAO YW, BEAURAIN G, BACH JF, HUANG HS, LUO DF, ZEIDLER A, ROTTER JI, YANG MC, MODILEVSKY T, MACLAREN NK, SHE JX: Insulin-dependent diabetes mellitus (IDDM) is associated with CTLA4 polymorphisms in multiple ethnic groups. Hum Mol Genet 6: 1275-1282, 1997.

MARTINKA E, SHAWKATOVÁ I, STRAKOVÁ J, BUC M, MOKAN M: Latent autoimmune (type I) diabetes mellitus in adults. Part. II. Association of HLA antigens, status of cellular immunity and occurrence of other autoimmune diseases. (in Slovak) Vnitrni Lek 45: 103-109,1999.

MAURER M, LOSERTH S, KOLB-MAURER A, PONATH A, WIESE S, KRUSE N, RIECKMANN P: A polymorphism in the human cytotoxic T-lymphocyte antigen 4 (CTLA4) gene (exon $1+49)$ alters T-cell activation. Immunogenetics 54: 1-8, 2002.

MEIN CA, ESPOSITO L, DUNN MG, JOHNSON GC, TIMMS AE, GOY JV, SMITH AN, SEBAG-MONTEFIORE L, MERRIMAN ME, WILSON AJ, PRITCHARD LE, CUCCA F, BARNETT AH, BAIN SC, TODD JA: A search for type 1 diabetes susceptibility genes in families from the United Kingdom. Nat Genet 19: 297-300, 1998.

MORAHAN G, HUANG D, YMER SI, CANCILLA MR, STEPHEN K, DABADGHA OP, WERTHER G, TAIT BD, HARRISON LC, COLMAN PG: Linkage disequilibrium of a type 1 diabetes susceptibility locus with a regulatory IL12B allele. Nat Genet 27: 131-132, 2001.

MUNTONI S, FONTE MT, STODUTO S, MARIETTI G, BIZZARRI C, CRINO A, CIAMPALINI P, MULTARI G, SUPPA MA, MATTEOLI MC, LUCENTINI L, SEBASTIANI LM, VISALli N, POZZILLI P, BOSCHERINI B, MUNTONI S: Incidence of insulin-dependent diabetes mellitus among Sardinian-heritage children born in Lazio region, Italy. Lancet 349: 160-162, 1997.

NAKAGAWA Y, KAWAGUCHI Y, TWELLS RC, MUXWORTHY C, HUNTER KM, WILSON A, MERRIMAN ME, COX RD, MERRIMAN T, CUCCA F, MCKINNEY PA, SHIELD JP, TUOMILEHTO J, TUOMILEHTO-WOLF E, IONESCO-TIRGOVISTE C, NISTICO L, BUZZETTI R, POZZILLI P., JONER G., THORSBY E., UNDLIEN DE, POCIOT F, NERUP J, RONNINGEN KS, BAIN SC, TODD JA: Fine mapping of the diabetes-susceptibility locus, IDDM4, on chromosome 11q13. Am J Hum Genet 63: 547-556, 1998. 
NEPOM GT: HLA and type I diabetes. In: HLA in Health and Disease. R. LECHLER, A. WARRENS (eds), Academic Press, New York, 2000, pp 231-237.

NOBLE JA, VALDES AM, THOMSON G, ERLICH HA: The HLA class II locus DPB1 can influence susceptibility to type I diabetes. Diabetes 49: 121-125, 2000.

NOEL PJ, BOISE LH, THOMPSON CB: Regulation of T cell activation by CD28 and CTLA4. Adv Exp Med Biol 406: 209-217, 1996.

NORRIS JM, BEATY B, KLINGENSMITH G, YU LIPING, HOFFMAN M, CHASE HP, ERLICH HA, HAMMAN RF, EISENBARTH GS, REWERS M: Lack of association between early exposure to cow's milk protein and beta-cell autoimmunity. Diabetes Autoimmunity Study in the Young (DAISY). JAMA 276: 609-614.

ONKAMO P, VAANANEN S, KARVONEN M, TUOMILEHTO J: Worldwide increase in incidence of Type I diabetes - the analysis of the data on published incidence trends Diabetologia 42: 1395-1403,1999.

PAUST S, LU L, MCCARTY N, CANTOR H: Engagement of B7 on effector T cells by regulatory T cells prevents autoimmune disease. Proc Natl Acad Sci USA 101: 10398-10403, 2004.

POCIOT F, MCDERMOTT MF: Genetics of type 1 diabetes mellitus. Genes Immun 3: 235-249, 2002.

REDONDO MJ, REWERS M, YU L, GARG S, PILCHER CC, ELLIOTT RB, EISENBARTH GS: Genetic determination of islet cells autoimmunity in monozygotic twin, dizygotic twin, and non-twin siblings of patients with type I diabetes: prospective twin study. BMJ 318: 698-702, 1999.

REDONDO MJ, KAWASAKI E, MULGREW CL, NOBLE JA, ERLICH HA, FREED BM, LIE BA, THORSBY E, EISENBARTH GS, UNDLIEN DE, RONNINGEN KS: DR- and DQ-associated protection from Type 1a diabetes: comparison of DRB1*1401 and DQA1*0102-DQB1*0602*. J Clin Endocrinol Metab 85: 37933797, 2000.

ROBLES DT, EISENBARTH GS.: Diabetes and related autoimmune diseases. In: Clinical Immunology. Principles and Praxis. RR RICH (ed), Mosby, St Louis, 2001, pp 82.1-82.18.

QUATRARO A, CONSOLI G, CERIELlO A, GIUGLIANO D: Heterogeneity of diabetes mellitus. Diabetologia 30: 678-679, 1987.

SALE MM, FITZGERALD LM, CHARLESWORTH JC, BOWDEN DW, RICH SS: Evidence for a novel type 1 diabetes susceptibility locus on chromosome 8. Diabetes $\mathbf{5 1}$ (Suppl 3): S316-S319, 2002.

SANJEEVI CB: HLA-DQ6-mediated protection in IDDM. Hum Immunol 61: 148-153, 2000.

SHAW MA, CLAYTON D, ATKINSON SE, WILLIAMS H, MILLER N, SIBTHORPE D. BLACKWELL JM: Linkage of rheumatoid arthritis to the candidate gene NRAMP1 on 2q35. J Med Genet 33: 672-677, 1996.

SMYTH D, COOPER JD, COLLINS JE, HEWARD JM, FRANKLYN JA, HOWSON JMM, VELLA A, NUTLAND S, RANCE HE, MAIER L, BARRATT BJ, GUJA C, IONESCU-TIRGOVISTE C, SAVAGE DA, DUNGER DB, WIDMER B, STRACHAN DP, RING SM, WALKER N, CLAYTON DG, TWELLS RCJ, GOUGH SCL, TODD JA: Replication of an association between the lymphoid tyrosine phosphatase locus (LYP/PTPN22) with type 1 Diabetes, and evidence for its role as a general autoimmunity locus. Diabetes 53: 3020-3023, 2004.

STASSI G, SCHLOOT N, PIETROPAOLO M: Islet cell autoantigen $69 \mathrm{kDa}$ (ICA69) is preferentially expressed in the human islets of Langerhans than exocrine pancreas. Diabetologia 40: 120-121, 1997.

STUCHLÍKOVÁ M, VRLÍKOVÁ D, BARÁK L', BUC M: Association of HLA-DPB1 alleles with type I diabetes mellitus in the Slovak population. Bratislava Med J 107: 73-75, 2006.

TANG Q, ADAMS JY, TOOLEY AJ, BI M, FIFE BT, SERRA P, SANTAMARIA P, LOCKSLEY RM, KRUMMEL MF, BLUESTONE J: Visualizing regulatory $\mathrm{T}$ cell control of autoimmune responses in nonobese diabetic mice. Nat Immunol 7: 83-92, 2006.

UEDA H, HOWSON JM, ESPOSITO L et al: Association of the T-cell regulatory gene CTLA4 with susceptibility to autoimmune disease. Nature 423: 506-511, 2003.

VALDES AM, NOBLE JA, GENIN E, CLERGET-DARPOUX F, ERLICH HA, THOMSON G: Modeling of HLA class II susceptibility to type I diabetes reveals an effect associated with DPB1. Genet Epidemiol 21: 212-223, 2001. 
VELLA A, COOPER JD, LOWE CE, WALKER N, NUTLAND S, WIDMER B, JONES R, RING SM, MCARDLE W, PEMBREY ME, STRACHAN DP, DUNGER DB, TWELLS RC, CLAYTON DG, TODD JA: Localization of a type 1 diabetes locus in the IL2RA/CD25 region by use of tag single-nucleotide polymorphisms. Am J Hum Genet 76: 773-779, 2005.

VENAZI ES, BENOIST CH, MATHIS D: Good riddance: thymocyte clonal deletion prevents autoimmunity. Curr Opin Immunol 16: 197-202, 2004.

VILLASENOR J, BENOIST C, MATHIS D: AIRE and APECED: molecular insights into an autoimmune disease. Immunol Rev 204: 156-164, 2005.

WAGENER DK, SACKS JM, LAPORTE RE, MACGREGOR JM: The Pittsburgh study of insulin-dependent diabetes mellitus. Risk for diabetes among relatives of IDDM. Diabetes 31: 136-144, 1982.

YOON JW, AUSTIN M, ONODERA T: Isolation of a virus from the pancreas of a child with diabetic ketoacidosis. N Engl J Med 30: 1173-1179, 1979.

ŽALKOVIČOVÁ M, BUC M, NIKS M, ŠTEFANOVIČ J: Genetic determination of phagocytic activity of polymorphonuclear leucocytes Folia Biol (Prague) 34: 240-247. 1988.

ZAMANI M, POCIOT F, RAEYMAEKERS P, NERUP J, CASSIMAN JJ: Linkage of type I diabetes to $15 \mathrm{q} 26$ (IDDM3) in the Danish population. Hum Genet 98: 491-496, 1996.

\section{Reprint requests}

D. Kantárová, Internal Clinic, Faculty Hospital, Kollárova 2, 03659 Martin, Slovakia. E-mail: daniela.v@pobox.sk 